\title{
Comentario al Real Decreto-ley 1/2017, de 20 de enero, de medidas urgentes de protección de consumidores en materia de cláusulas suelo
}

Javier Ibáñez Jiménez

La sentencia del 21 de diciembre del Tribunal de Justicia de la Unión Europea impuso a los bancos europeos la devolución retroactiva a sus clientes de lo cobrado en virtud de la muy extendida cobertura de riesgo de tipos de interés conocida como "cláusula hipotecaria suelo" que fijaba un interés mínimo a pagar por el cliente hipotecario con préstamo a interés variable, si los tipos bajaban en el mercado. En general, ese interés "suelo" ha rondado en los contratos torno al 2,5\% anual, lo que ha resultado en elevadas pérdidas para los clientes, si se considera que el tipo de interés bancario europeo de referencia o Euribor ronda una media del $0,06 \%$ en el último bienio, llegando a ser negativo; así, el 24 de febrero de 2107 fue el $-0,11 \%$.

Las cláusulas han sido impugnadas en unos casos por falta de transparencia de los bancos hacia sus clientes durante la fase formativa del contrato (tratos preliminares, donde los clientes no conocían la naturaleza del riesgo, una apuesta con productos derivados); en otros, por su imposición unilateral y abusiva en otros (otros clientes conocían el riesgo, pero no habrían tenido otras alternativas razonables para contratar); y en otros, en fin, por fraude del banco (el cliente conocía el riesgo, pero no su magnitud, y contrató sin saber que perdería la apuesta, a diferencia del banco).

La sentencia referida contradijo a importantes tribunales de los Estados miembros de la Unión Europea, entre otros al Supremo español, que fallaron en 2013 en contra de la devolución retroactiva del dinero liquidado en aplicación de la cláusula suelo, apoyando así a los bancos; según estos, la cláusula era válida, fruto de la libertad contractual, y los consumidores la habrían aceptado libremente.

Director del Observatorio Jurídico Fintech. Universidad Pontificia Comillas (Madrid) 
A fin de adecuarse al criterio europeo, el Gobierno español acaba de aprobar el Real Decreto-ley 1/2017, de 20 de enero, de medidas urgentes de protección de consumidores en materia de cláusulas suelo, que regula un sistema extrajudicial para pactar la devolución al cliente del dinero ya cobrado por el banco al aplicar el "suelo": en España, decenas de miles de millones de euros. Así, bancos y clientes damnificados puedan acordar tiempo y cantidad a devolver, lo que ha desatado las críticas de las asociaciones de consumidores (hay un millón y medio de afectados en España), que desconfían del posible abuso de los bancos al seleccionar clientes para negociar en esa vía extrajudicial.

El Real-Decreto Ley regulador de esta conciliación extrajudicial entró en vigor el lunes 23 de enero de 2017, pero el procedimiento está en marcha desde finales de febrero; desde entonces los afectados por una cláusula suelo pueden reclamar en su banco. Este estudiará las reclamaciones y decidirá a qué clientes cobró indebidamente el interés mínimo o "suelo", superior al que habría resultado del préstamo variable sin aplicar dicha cláusula. A partir de junio de 2017 los bancos enviarán a sus clientes el cálculo de la devolución propuesta, plazo que aliviará la congestión actual de los tribunales para atender este tipo de demandas. Con todo, el perjudicado puede, al amparo del Real-Decreto Ley comentado, proseguir las demandas judiciales que hubiere iniciado, o incoar otras nuevas si no llega a un consenso con el banco.

Naturalmente, los clientes a cuyo banco no les reconozca la devolución optarán por la vía judicial; pero gracias a la nueva norma, los perjudicados tendrán información adicional o nueva para demandar a sus entidades bancarias puesto que, conforme a estas reglas, deben recibir del prestador hipotecario un documento explicando por qué rechazan una solicitud y por qué no consideran irregular una cláusula; es decir, por qué entienden que es transparente, no abusiva o que en ella no concurre dolo o engaño.

En principio, la banca excluirá de las devoluciones a los reclamantes profesionales, invocando su alta formación financiera; y estimará probablemente las que pidan clientes sin formación (pensionistas, jubilados, personas sin estudios), a los que reintegrará según el nuevo régimen la totalidad de lo cobrado con intereses, desde el día en que empezó a aplicarse el "suelo". El principal devuelto habrá de computar como ingreso fiscal del cliente si este hubiera gozado 
ciertas deducciones en su declaración de la renta personal

En relación con determinadas precisiones técnico-jurídicas del Real Decreto-Ley 1/2007 especialmente relevantes para el desenvolvimiento de las reclamaciones comentadas, debe tenerse en cuenta que:

a) Respecto al cliente, este ha de ser "consumidor" persona física en el sentido del art. 3 del texto refundido de la Ley General para la Defensa de los Consumidores y Usuarios y (Real Decreto Legislativo 1/2007, de 16 de noviembre; cf. art. 1 RDL 1/2007). Sin embargo, algunos jueces han incluido en el concepto de consumidor a pequeñas empresas que contrataron una hipoteca fuera de su actividad empresarial.

b) El "suelo" es el aplicado para garantizar al banco cobros de interés mínimos, tanto en préstamos de cantidad fija como en contratos de apertura de crédito o créditos de límite; en ambos casos, a condición de que el interés se haya fijado a tipo variable (o mixto, si hay tramo variable) y además de que exista garantía real inmobiliaria.

c) El procedimiento, voluntario y gratuito (art. 3 y Disposición Adicional $3^{\mathrm{a}}$ RDL 1/2007), si se sigue y mientras no concluya, veda el acceso a la vía judicial o al arbitraje, evitándose así que se abuse del mismo cargando al banco con dobles costes, pues los entidades han organizar un "servicio de reclamaciones de cláusulas suelo" con webpage, email y personal que resuelva en tres meses como máximo el expediente.

d) La comunicación del cálculo de la devolución practicado por el banco ha de incluir desglose de intereses de la cantidad propuesta; el cliente ha de manifestar si eventual conformidad, y caso de darse esta, el banco abonará el efectivo pactado en su cuenta.

e) La comunicación de improcedencia de la devolución será motivada, como se ha indicado, y termina automáticamente el procedimiento. También lo concluye el transcurso de tres meses sin respuesta del banco a la petición del cliente, con aceptación automática de su pretensión; y asimismo la falta de ingreso de la cantidad en el mismo plazo. 
f) El cliente puede aceptar devoluciones en especie, en especial rebajas del principal del préstamo, con tratamiento fiscal favorable. Estas negociaciones, como todas las relativas a la devolución, no pueden extenderse más allá de tres meses desde el tiempo de presentación de la reclamación que inicia el procedimiento.

g) El coste notarial y registral surgido del pacto entre entidad y cliente está limitado a aranceles fijos, al margen de la cuantía pactada.

h) El consumidor que rechace la oferta del banco, lo demande (ex novo o bien continuando su anterior reclamación interrumpida o suspendida), y obtenga del juez un importe superior al ofertado, no abonará costas judiciales; lo hará el banco.

i) Si el consumido no acude a este procedimiento, entabla juicio y la entidad se allana o aviene a pagar lo reclamado antes de contestar la demanda, se estimará que obró de buena fe a los fines previstos en el art. 395.1.2 de la Ley $1 / 2000$, de 7 de enero, de Enjuiciamiento Civil; y si se aviene en parte en dicho momento procesal, solo pagará costas si el cliente logra del juez importe que el ofrecido y consignado por el banco.

j) El Gobierno, en desarrollo del RDL 1/2017, dispondrá de un organismo supervisor y evaluador de las reclamaciones que informará de su actuación cada semestre, e incluirá representación de los consumidores y de la abogacía. 